\section{Factors associated with readmission to a general hospital in Brazil}

\author{
Fatores associados às readmissões hospitalares \\ em um hospital geral brasileiro
}

\footnotetext{
1 Escola Nacional de Saúde Pública, Fundação Oswaldo Cruz, Rio de Janeiro, Brazil.

2 Centro de Informação Científica e Tecnológica, Fundação Oswaldo Cruz, Rio de Janeiro, Brazil.

Correspondence M. S. M. Castro Escola Nacional de Saúde Pública, Fundação Oswaldo Cruz. Rua Engenheiro Amaro Lanari 355, apto. 601, Belo Horizonte, $M G$ 30310-580, Brazil. mmcastro@uai.com.br mmcastro@procc.fiocruz.br
}

\section{Abstract}

The objective of this study was to compare different modeling strategies to identify individual and admissions characteristics associated with readmission to a general hospital. Routine data recorded in the Hospital Information System on all admissions to the Regional Public Hospital of Betim, Minas Gerais State, Brazil, from July 1996 to June 2000 were analyzed. Cox proportional hazards model and variants designed to deal with multiple-events data, like AndersenGill (AG), Prentice, Williams and Peterson (PWP), and random effects models were fitted to time between hospital admissions or censoring. For comparison purposes, a Poisson model was fitted to the total number of readmissions, using the same covariates. We analyzed 31,648 admissions of 26,198 patients, including 17,096 adults and 9,102 children. Estimates for the PWP and frailty models were very similar, and both approaches should be fitted and compared. If clinical characteristics are available, the PWP model should be used. Otherwise the random effects model can account for unmeasured differences, particularly some related to severity of the disease. These methodologies can help focus on various related readmission aspects such as diagnostic groups or medical specialties.

General Hospitals; Hospital Readmission; Survival Analysis
Mônica Silva Monteiro de Castro 1

Marilia Sá Carvalho 1

Cláudia Travassos 2

\section{Introduction}

Multiple hospital admissions have rarely been studied, particularly in Brazil. Unnecessary rehospitalization means unnecessary costs for the social security system and undue risks for patients. In this paper, four different survival models were applied to analyze time between successive admissions, in order to identify associated risk factors.

Hospital readmission can be defined as patient admission to a hospital within a certain period after discharge from the same hospital 1 . The time span varied in the literature from thirty days 2 to several years 3 . Early readmission can be used as a marker for premature discharge and other problems related to the quality of hospital care. Longer time intervals are more often related to chronic diseases, socioeconomic conditions, and limited access to outpatient care.

Heavy users of hospital services are characterized by a pattern of repeated admissions 4,5 . In the United States, a minority of Medicare users $(5.0 \%)$ is responsible for a majority of admission days (55.0\%) and hospital expenses (62.0\%) 6. Between 1974 and 1977, nearly $22.0 \%$ of Medicare discharges were followed by readmission within sixty days 7 , a situation also described in Canada 8. In Brazil, heavy use of hospital services was associated with health needs, socioeconomic and enabling factors such as 
health insurance coverage, and availability of a regular health service 9 .

After a first admission, a patient can be readmitted for a different acute disease or for a planned intervention. Alternatively, readmission to treat the same initial disease can be related to low effectiveness of hospital care, inadequate out-patient care after discharge, or the disease itself, whether chronic or terminal. Finally, some readmissions are unnecessary, based on reasons other than clinical need.

The following factors are associated with readmissions: (i) individual characteristics age, sex, marital status, education, occupation, and income; (ii) clinical aspects - type and severity of the disease; (iii) health services supply characteristics - hospital type and patterns of medical practice; and (iv) place of residence and health care access. The relative weight of each factor is decisive for defining admission priorities in public hospitals. If such factors are clinically justified, to dissuade re-hospitalization can be harmful. On the other hand, if readmissions are related to social factors or hospital characteristics, clinically superior and more cost-effective alternatives can be encouraged 2 .

In several studies in the United States 1,2,6,7, 10,11,12, using different methods and time limits, the individual characteristics associated with readmission were: age, male sex, nonwhite race, widow(er) or single marital status, living alone or in a home or institution for the elderly, and having supplemental Medicaid coverage. Health needs factors identified were: poor self-rated health status, poor mental status, low life-satisfaction index, functional disability, two or more chronic diseases, associated psychiatric disease and a history of coronary disease, more than six consultations, or diabetes in the last year. Characteristics associated with the previous admission were: initial treatment in the emergency department before admission, more severe disease as the principal diagnosis, history of two or more surgical procedures, discharge from a geriatric or intermediate care unit, and diagnosis of chronic disease. Considering the supply of hospital services, readmissions were associated with previous admissions to hospitals with fewer than a hundred beds and greater distance between place of residence and the hospital.

The effect of length of stay on readmission rates is complex: in some studies, shorter length of stay was associated with an increase in the readmission rate 13,14 and long-term need for home care 15 . Other studies found that extended length of stay was associated with a higher readmission risk for surgical patients 16 , in this case longer periods indicating greater disease severity.

Planning the supply of hospital services and the need to optimize health care systems' resources are of great relevance in health services research. In this paper, different strategies to model time between admissions were compared, aimed at detecting individual and previous hospitalization characteristics associated with increased risk of readmission to a general hospital in the city of Betim, Minas Gerais, Brazil.

\section{Methodology}

\section{Data}

Data for all patients admitted to the Betim Regional Public Hospital from July 1996 to June 2000 were obtained from the Brazilian Hospital Admissions Information System. This system, designed for payment purposes, contains data on all patients whose hospitalizations are covered by public funding and is updated monthly. The public health care system in Brazil, known as the Unified National Health System (SUS), is based on universal and publicly funded access to health care. Nearly $70.0 \%$ of the population uses SUS services regularly; the other $30.0 \%$ uses it only occasionally and generally for more complex or expensive services. The Betim Regional Public Hospital is a general hospital with 270 beds and is the only public general hospital in Betim. Betim is located in the greater metropolitan area of Belo Horizonte, the capital of Minas Gerais State, Brazil, and had 285,522 inhabitants in 1998 (http:// www.datasus.gov.br, accessed on 12/Jan/2002).

The data set showed 47,638 hospital admissions corresponding to 38,696 individuals, varying from 1 to 19 admissions each. Each patient was identified in the hospital data set by a unique patient number, so all admissions of a same patient were already linked. Hospitalizations were analyzed using a chronological structure. All admissions following the first one were considered readmissions, regardless of the time interval. In order to limit the analysis to clinical and surgical patients, 11,062 patients with admissions to the obstetric ward only were excluded. We also excluded 1,436 individuals who died during the first hospitalization. The re- 
maining 31,648 admissions of 26,198 patients were divided into two groups: adults and children. The first group included 21,416 admissions of 17,096 patients over 14 years of age old at the date of the first admission, and the second consisted of 10,232 admissions of 9,102 children up to 14 years old at the date of the first admission.

Time until readmission or censoring by death or end of the observation period was modeled, using the following independent covariates: sex, age, length of stay during the previous hospitalization, death during the subsequent hospitalization (for adults), medical specialty, and diagnosis on previous admission.

According to the Brazilian Ministry of Health guidelines, the main diagnosis for each admission was coded using the 9 th Revision of the International Classification of Diseases (ICD-9) 17 from 1996 and 1998 and the 10th Revision (ICD10) 18 thereafter. To include this important covariate in the models, different approaches were tested. The most common one, grouping diagnoses in chapters, was considered too nonspecific for the readmission problem. On the other hand, the ICD three-digit groups were too numerous. Therefore, in order to incorporate the principal diagnosis in a meaningful way, admissions were classified as follows (see Castro et al. 19 for more details):

- an equivalence table between ICD-9 and ICD-10 was used, considering three-digit groups of both classifications (141 groups for ICD-9 and 234 groups for ICD-10);

- groups with fewer cases were combined as long as clinical coherence concerning readmission risk was maintained, resulting in 33 groups; - a Cox proportional hazards model 20 was fitted, considering only time to first readmission for adults and children as a guide to the next step: groups with fewer than a hundred patients were combined with another group from the same ICD chapter if the hazard ratios (HR) for both groups were in the same direction and of similar magnitude. Otherwise, groups with different or non-significant hazard ratios, together with the groups "symptoms, signs, and ill-defined conditions", and "factors influencing contact with health services" were combined in a group called "others". At the end of this process we had 26 diagnostic groups for adults and 19 for children, used as categorical variables for modeling;

- the reference groups chosen were "diseases of the appendix" for adults and "hernias" for children, both with small readmission risk according to clinical criteria.

\section{Survival models}

The models fitted were: (i) the classical Cox proportional hazards model using only time to first readmission; (ii) two different proposals for marginal models, the Andersen-Gill (AG) and the Prentice, Williams, and Peterson (PWP) models; and (iii) a random effects model, referred to as a frailty model in survival analysis 21 . A Poisson linear model was also fitted to the total number of readmissions, for comparative purposes.

The AG model, also called an independent increments model, is recommended to model mutually independent observations of each individual. In this case, counts of events in distinct time intervals are independent, given the covariates. No extra strata are induced by the multiple events; the use of strata is based on the same considerations as for an ordinary single-event model.

In the PWP or "conditional" model, the individuals are at risk of the $k$-th event only if they presented the $(k-1)-t h$ event. Unlike the AG model, each event belongs to a different and ordered stratum (first readmission, second readmission, and so on). The use of time-dependent strata means that the underlying intensity function can vary from event to event, whereas in the AG model the probability of any event is identical.

In survival analysis, frailty models associate a random effect for each individual in order to account for effects of over-dispersion, possibly due to unmeasured covariates. The random effect can be thought of as a frailty, increasing individual susceptibility to readmission when it is large and decreasing susceptibility when it is small.

Considering that readmissions are not mutually independent observations and that they are ordered events, in theory, as explained above, the most appropriate model would be the conditional one. Given the absence of important covariates like clinical characteristics, the frailty model is another good choice, as will be highlighted in the discussion. The other models were adjusted for comparative purposes.

All models are fitted using a counting process notation as described in Therneau \& Grambsh 21 , and the data set was prepared accordingly. The main difference vis-à-vis the more common notation is that an indicator for the start and end of each interval between admissions is used instead of just the time span. It should be noted that this maintains the calendar time flow, eliminating the artificial increase in the risk set at the beginning of the study period that 
would occur if all observations were brought to a theoretical time zero. The assumption of proportionality of risks was assessed using Schoenfeld's residuals analysis 21 . For all variables, the assumption of proportionality of risks was confirmed. We used the public domain statistical package $\mathrm{R} 22$.

\section{Results}

Nearly one fifth (18.0\%) of all admissions were readmissions, and $15.0 \%$ of patients had at least one readmission. All patients were Brazilian, from the State of Minas Gerais; $62.0 \%$ were women and $80.0 \%$ were Betim residents. Surgery and obstetrics wards admitted $28.0 \%$ of patients each, and internal medicine and pediatrics $27.0 \%$ and $17.0 \%$ respectively. Only the main diagnosis was recorded in approximately $80.0 \%$ of admissions.

In adults, median time until readmission was one year and two months. Kaplan-Meier plots to illustrate the effect of each variable are shown in Figure 1, with group definitions provided in the legends and group sizes and median times shown in Table 1. Log-rank tests for survival differences were all highly significant ( $p<0.000$ ), as expected in such a large data set. Time between admissions was inversely related to the number of previous admissions and to hospital length of stay in the preceding admission. Patient death often followed a short interval between admissions. These findings characterize a subgroup of heavy users of hospital services. Admission to the obstetric ward presented the smallest median time interval between admissions, because only obstetric cases with admissions to other medical specialties remained in the data set. The groups with shorter median time interval between admissions were "renal failure" (80 days) and "liver diseases" (216 days).

In children, the median global time to readmission was one year and four months. Kaplan-Meier plots are shown in Figure 2, and group sizes and median times in Table 2. Except for sex, log-rank tests for survival differences were also all highly significant $(\mathrm{p}<0.000)$. The 10-to-14-year age group had the shortest median time interval. The associations between readmission numbers, length of stay, and median times were less clear than for adults, suggesting that children were readmitted to treat acute disease episodes that were not interrelated. Death followed short time intervals after previous admission. However, the small number of deaths in children precluded including this variable in the multivariate models. Admissions to the surgical ward and for "eye, ear, and mastoid process diseases" had the shortest median times.

Table 3 shows the estimates for the adult model. Compared to both PWP and frailty models, in general, the coefficients were smaller for all variables when fitting the Poisson model, and larger using the AG model. Estimated variance of the random effect in the frailty model was 1.51 , strongly indicating the presence of individual variability in readmission risk not explained by the covariates included in the model.

For an increment of one year in age, there was an increase of about $1.0 \%$ in the risk of readmission. Each additional day in length of stay during the previous admission led to an increase of 1.0 to $1.5 \%$ in risk. The most important factor associated with repeated admissions was death in the final admission, with a HR above 10 in all models. Obstetrics, internal medicine, and pediatrics specialties had a greater risk than surgery. It is worth mentioning that individuals over 14 years old with admissions to the pediatric unit are probably those with chronic health problems beginning in childhood. In the frailty model, the effect of admission to the obstetric ward lost significance, suggesting the possible influence of unmeasured covariates related to admissions to this medical specialty.

In the PWP model, when compared to "diseases of the appendix", the groups with HR greater than 2 were: "liver diseases" (2.44), "diseases of the gallbladder, bile ducts and pancreas" (2.02), "renal failure" (4.06), "complications of pregnancy, childbirth, and the puerperium" (3.53), and "diseases of skin and subcutaneous tissue” (2.20). Four groups were significant in the PWP model but not in the frailty model: "blood, blood-forming organs, and immunity disorders", "diseases of the urinary system", "neoplasms", and "nervous system diseases". The explanation may be related to the effect of unmeasured covariates associated with these causes of hospitalization, better expressed by the random effects model.

Table 4 shows the estimated effects of covariates for children. Both the Poisson and AG models presented the same behavior as with the adult data set: smaller coefficients for the Poisson and larger for the AG, even more than for adults, almost doubling the HR for some covariates. The variance of the random effects model was 6.07 , suggesting that individual frailty was even greater for children than for adults.

Readmission risk is greater for younger children: for an increment of one year in age 
Figure 1

Kaplan-Meier plots for sex, age (in years), number of admissions, length of stay (in days), death in the final admission, and medical specialty - adults. Regional Public Hospital of Betim, Minas Gerais, Brazil, 1996/2000.
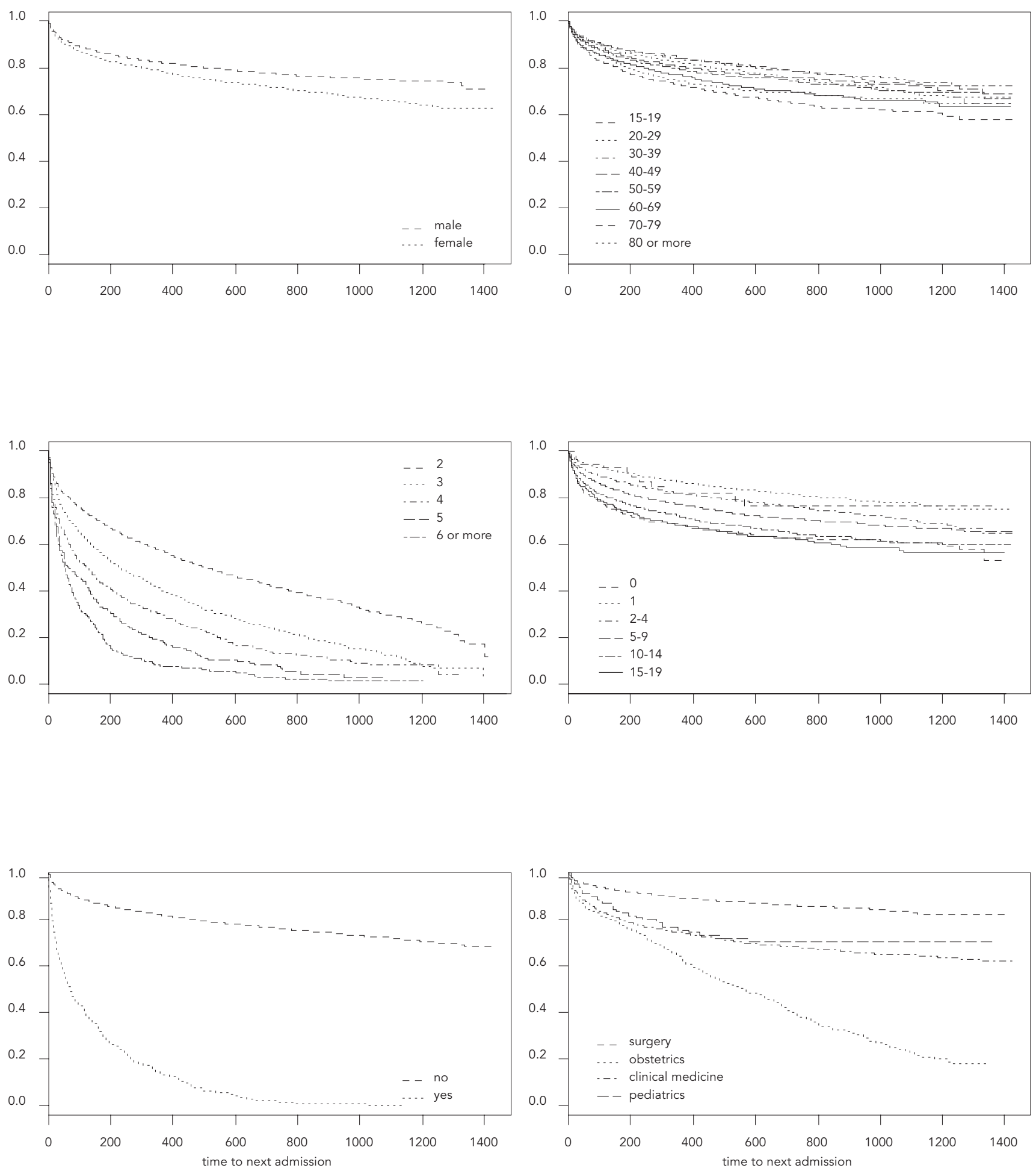
Frequency distribution and median time until subsequent admission in individuals over 14 years of age, Betim Regional Public Hospital. Minas Gerais State, Brazil, 1996/2000.

\begin{tabular}{|c|c|c|c|}
\hline Characteristic & Frequency & $\%$ & Median time (days) \\
\hline Global median time & 21,416 & & 416 \\
\hline \multicolumn{4}{|l|}{ Sex } \\
\hline Male & 10,715 & 50 & 419 \\
\hline Female & 10,701 & 50 & 413 \\
\hline Total & 21,416 & 100 & \\
\hline \multicolumn{4}{|l|}{ Age (years)* } \\
\hline $15-19$ & 2,129 & 10 & 453 \\
\hline $20-29$ & 4,175 & 19 & 448 \\
\hline $30-39$ & 4,090 & 19 & 445 \\
\hline $40-49$ & 3,557 & 17 & 393 \\
\hline $50-59$ & 2,495 & 12 & 392 \\
\hline $60-69$ & 2,374 & 11 & 394 \\
\hline $70-79$ & 1,755 & 8 & 360 \\
\hline 80 or over & 841 & 4 & 398 \\
\hline Total & 21,416 & 100 & \\
\hline \multicolumn{4}{|l|}{ Admissions } \\
\hline 1 & 13,891 & 65 & 544 \\
\hline 2 & 4,355 & 20 & 271 \\
\hline 3 & 1,658 & 8 & 168 \\
\hline 4 & 711 & 3 & 93 \\
\hline 5 & 317 & 1 & 57 \\
\hline 6 and more & 484 & 2 & 50 \\
\hline Total & 21,416 & 100 & \\
\hline \multicolumn{4}{|l|}{ Length of stay (days) } \\
\hline 0 & 58 & 0 & 529 \\
\hline 1 & 6,040 & 28 & 438 \\
\hline $2-4$ & 7,487 & 35 & 433 \\
\hline $5-9$ & 4,050 & 19 & 412 \\
\hline $10-14$ & 1,627 & 8 & 353 \\
\hline $15-19$ & 812 & 4 & 327 \\
\hline 20 or over & 1,342 & 6 & 328 \\
\hline Total & 21,416 & 100 & \\
\hline \multicolumn{4}{|c|}{ Death (during next admission) } \\
\hline No & 21,004 & 98 & 426 \\
\hline Yes & 412 & 2 & 73 \\
\hline Total & 21,416 & 100 & \\
\hline \multicolumn{4}{|l|}{ Specialty } \\
\hline Surgery & 9,655 & 45 & 419 \\
\hline Obstetrics & 869 & 4 & 346 \\
\hline Internal medicine & 10,763 & 50 & 423 \\
\hline Pediatrics & 129 & 1 & 397 \\
\hline Total & 21,416 & 100 & \\
\hline
\end{tabular}

(continued) 


\begin{tabular}{|c|c|c|c|}
\hline Characteristic & Frequency & $\%$ & Median time (days) \\
\hline \multicolumn{4}{|l|}{ ICD group } \\
\hline Appendix & 814 & 4 & 467 \\
\hline Infectious and parasitic & 444 & 2 & 447 \\
\hline Neoplams & 415 & 2 & 490 \\
\hline Endocrine, nutritional, and metabolic & 571 & 3 & 423 \\
\hline Blood, blood-forming organs, and immunity & 196 & 1 & 470 \\
\hline Esophagus, stomach, and duodenum & 263 & 1 & 490 \\
\hline Hernias & 766 & 4 & 399 \\
\hline Intestines and peritoneum & 301 & 1 & 374 \\
\hline Other digestive diseases & 444 & 2 & 378 \\
\hline Liver & 193 & 1 & 216 \\
\hline Gallbladder, bile ducts, and pancreas & 896 & 4 & 360 \\
\hline Nervous system & 1,095 & 5 & 446 \\
\hline Cardiovascular, exc. vein and lymphatic diseases & 2,915 & 14 & 364 \\
\hline Vein and lymphatic diseases & 536 & 3 & 443 \\
\hline Acute respiratory infections & 607 & 3 & 567 \\
\hline Other respiratory diseases & 306 & 1 & 317 \\
\hline Chronic lower respiratory diseases & 625 & 3 & 435 \\
\hline Urinary diseases & 650 & 3 & 545 \\
\hline Male genital diseases & 175 & 1 & 313 \\
\hline Female genital diseases & 742 & 3 & 427 \\
\hline Renal failure & 348 & 2 & 80 \\
\hline Pregnancy, childbirth, and puerperium & 1,337 & 6 & 331 \\
\hline Skin and subcutaneous tissue & 459 & 2 & 358 \\
\hline Musculoskeletal and connective tissue & 453 & 2 & 429 \\
\hline Injuries and poisoning & 4,747 & 22 & 456 \\
\hline Other diseases & 1,118 & 5 & 502 \\
\hline Total & 21,416 & 100 & \\
\hline
\end{tabular}

* Mean 43.71; standard deviation 19.23.

there was a decrease of 3.0 to $6.0 \%$ in risk. An increment of one day in previous length of stay was associated with an increase of about $1.5 \%$ in readmission risk. Pediatrics specialty had a protective effect according to the Cox and AG models.

In general, the estimated coefficients for the ICD groups were greater for children than for adults. In the PWP model, compared to "hernias", groups with an HR that was significant and greater than 2 were: "blood, blood-forming organs, and immunity disorders" (5.13), "diseases of the appendix" (2.23), "intestinal and peritoneal diseases” (2.12), "nervous system diseases" (4.73), "eye, ear, and mastoid process diseases" (4.17), "circulatory diseases" (2.61), "acute respiratory diseases" (2.08), "chronic lower respiratory diseases" (2.67), "male genital diseases” (2.09), “congenital anomalies” (4.34), and "other diseases" (2.06). This last group includes "neoplasms", "endocrine, nutritional and metabolic diseases", "female genital dis- eases", "renal failure", "complications of pregnancy, childbirth and the puerperium", "symptoms, signs, and ill-defined conditions", "factors influencing contact with health services", and "unknown causes". All significant ICD groups in the PWP model remained significant in the frailty model. However, three groups "diseases of the appendix", "eye, ear, and mastoid process diseases", and "congenital anomalies" - had their coefficients markedly increased in the frailty model, again expressing the importance of individual characteristics in explaining readmissions for patients previously admitted with those diagnoses.

\section{Discussion}

It is important to study hospital readmissions, due to the high levels of hospital costs, especially in countries with limited available public budget funds for health care, such as Brazil and other 
Figure 2

Kaplan-Meier plots for sex, age (in years), number of admissions, length of stay (in days), and medical specialty - children. Regional Public Hospital of Betim, Minas Gerais, Brazil, 1996/2000.
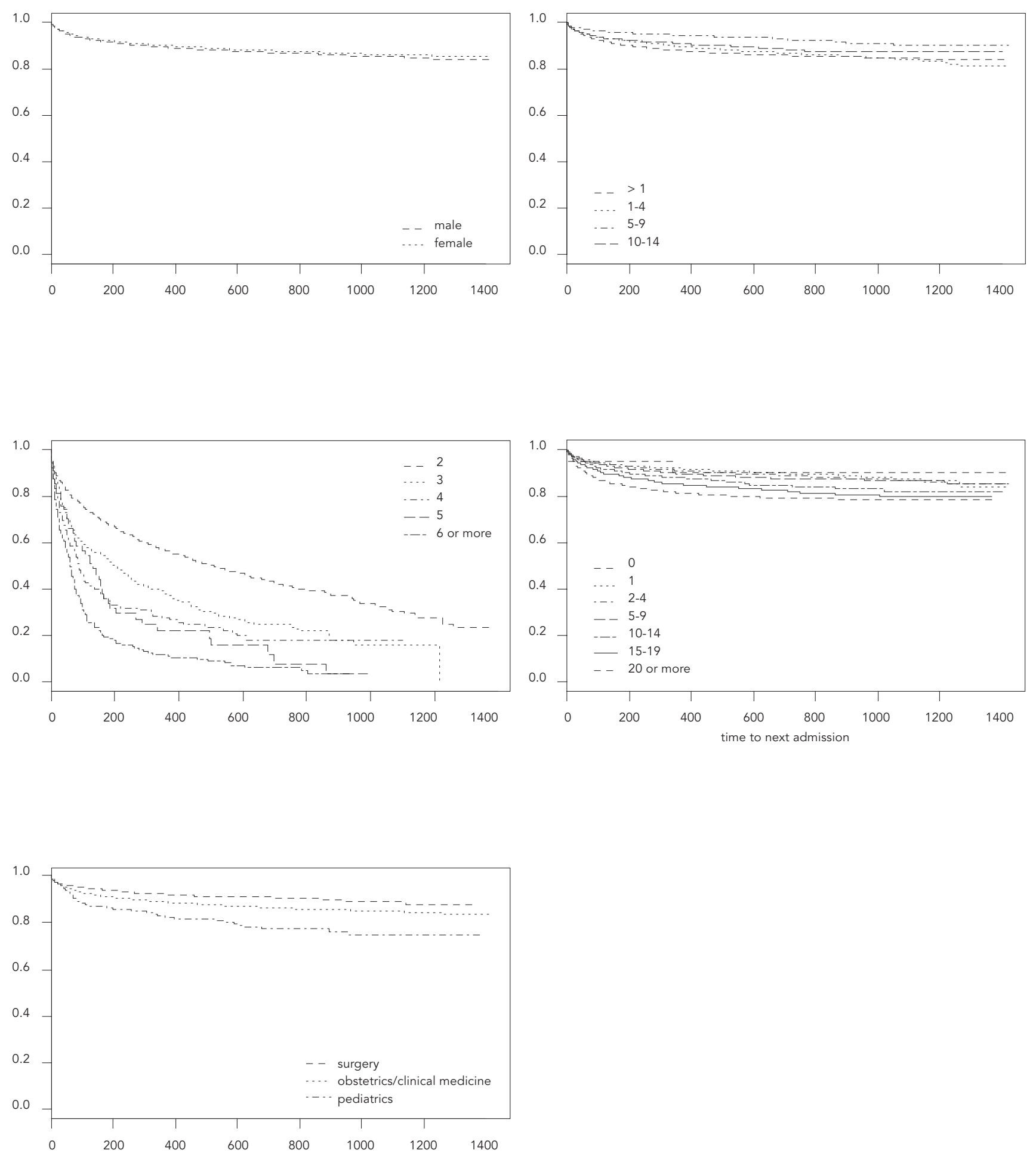
Frequency distribution and median times until subsequent admission of individuals under14 years of age, Betim Regional Public Hospital. Minas Gerais State, Brazil, 1996/2000.

\begin{tabular}{|c|c|c|c|}
\hline Characteristic & Frequency & $\%$ & Median time (days) \\
\hline Global median time & 10,232 & & 500 \\
\hline \multicolumn{4}{|l|}{ Sex } \\
\hline Male & 5,652 & 55 & 484 \\
\hline Female & 4,580 & 45 & 520.5 \\
\hline Total & 10,232 & 100 & \\
\hline \multicolumn{4}{|l|}{ Age (years)* } \\
\hline Under 1 & 5,012 & 49 & 508.5 \\
\hline $1-4$ & 2,611 & 26 & 510 \\
\hline $5-9$ & 1,549 & 15 & 505 \\
\hline $10-14$ & 1,060 & 10 & 454 \\
\hline Total & 10,232 & 100 & \\
\hline \multicolumn{4}{|l|}{ Admissions } \\
\hline 1 & 8,305 & 81 & 588 \\
\hline 2 & 1,197 & 12 & 259 \\
\hline 3 & 332 & 3 & 161.5 \\
\hline 4 & 148 & 1 & 85.5 \\
\hline 5 & 55 & 1 & 120 \\
\hline 6 and more & 195 & 2 & 61 \\
\hline Total & 10,232 & 100 & \\
\hline \multicolumn{4}{|l|}{ Length of stay (days) } \\
\hline 0 & 22 & 0 & 858.5 \\
\hline 1 & 2,394 & 23 & 490.5 \\
\hline $2-4$ & 2,719 & 27 & 481 \\
\hline $5-9$ & 2,585 & 25 & 506 \\
\hline $10-14$ & 1,150 & 11 & 554.5 \\
\hline $15-19$ & 490 & 5 & 522.5 \\
\hline 20 or over & 872 & 9 & 500.5 \\
\hline Total & 10,232 & 100 & \\
\hline \multicolumn{4}{|l|}{ Death (during next admission) } \\
\hline No & 10,203 & 100 & 503 \\
\hline Yes & 29 & 0 & 46 \\
\hline Total & 10,232 & 100 & \\
\hline \multicolumn{4}{|l|}{ Specialty } \\
\hline Surgery & 2,494 & 24 & 472 \\
\hline Obstetrics and internal medicine & 364 & 4 & 509 \\
\hline Pediatrics & 7,374 & 72 & 517 \\
\hline Total & 10,232 & 100 & \\
\hline
\end{tabular}




\begin{tabular}{|c|c|c|c|}
\hline Characteristic & Frequency & $\%$ & Median time (days) \\
\hline \multicolumn{4}{|l|}{ ICD group } \\
\hline Hernias & 357 & 3 & 659 \\
\hline Infectious and parasitic & 1,086 & 11 & 471 \\
\hline Blood, blood-forming organs, and immunity & 128 & 1 & 310.5 \\
\hline Appendix & 206 & 2 & 445.5 \\
\hline Intestines and peritoneum & 207 & 2 & 583 \\
\hline Nervous system & 283 & 3 & 324 \\
\hline Eye, ear, and mastoid process & 99 & 1 & 288 \\
\hline Circulatory & 101 & 1 & 443 \\
\hline Acute respiratory infections & 1,649 & 16 & 539 \\
\hline Other respiratory diseases & 348 & 3 & 361 \\
\hline Chronic lower respiratory diseases & 652 & 6 & 407 \\
\hline Urinary diseases & 274 & 3 & 588 \\
\hline Male genital diseases & 115 & 1 & 573 \\
\hline Skin and subcutaneous tissue & 291 & 3 & 638 \\
\hline Musculoskeletal and connective tissue & 149 & 1 & 476 \\
\hline Congenital anomalies & 218 & 2 & 354 \\
\hline $\begin{array}{l}\text { Certain conditions originating } \\
\text { in the perinatal period }\end{array}$ & 2,293 & 22 & 575 \\
\hline Injuries and poisoning & 1,236 & 12 & 481 \\
\hline Other diseases & 540 & 5 & 521 \\
\hline Total & 10,232 & 100 & \\
\hline
\end{tabular}

* Mean 3.09; standard deviation 3.99.

developing nations. In addition, since the public health system in Brazil - called SUS - guarantees universal access to hospital care for those who need it, assessment of hospital use is crucial.

All models tested in our study displayed similar behaviors, with HRs that were significant and pointing in the same direction, due in part to the robustness of the large data set. The most dissimilar results came from the Poisson model, with smaller coefficients, showing the effect of not using the time to event information in the analysis of readmission data. The larger coefficients estimated by the AG model were expected, induced by the conceptual limits of this model for grasping the correlation structure of observations, since it does not treat the admissions in ordered strata.

For adults, the results of the Cox model using only the first readmission were closer to the PWP and frailty models, suggesting that in this particular case the profiles of the first readmissions were similar to those of subsequent ones. In children, the Cox model results were similar to the AG ones, suggesting that the first readmission's profile is different from that of subsequent ones. The similar results of the PWP and frailty models reinforced our previous idea that both models were appropriate for the analysis of hospital readmissions.
Considering the appropriateness and similar results of the PWP and frailty models, both should be explored when modeling re-hospitalization. The PWP model is the best approach if clinical variables are available, since they are important to explain readmission risk. Otherwise, we suggest the use of the frailty model, since it allows for unmeasured individual characteristics. The AG model is not appropriate for the analysis of ordered repeated events, and in fact our analysis confirmed this inadequacy. Neither is the Cox model for the first readmission only indicated for this problem, unless there is evidence that discarding subsequent readmissions would not affect results. In general, the models for children presented a worse fit. Although the smaller data set can be a possible explanation, readmissions in this age group are presumably not as predictable as for adults.

For both adults and children, readmissions were associated with severity of disease, indirectly measured through death occurring in the final hospitalization and length of stay in the immediately previous one. Death in the final admission can not be used for prediction purposes in a readmission model because it is only available for analysis after its occurrence and after all admissions of a patient had also occurred. Unfortunately it was not possible to 
Table 3

Model comparison, admissions to Betim Regional Public Hospital, individuals over 14 years of age. Minas Gerais State, Brazil, $1996 / 2000$.

\begin{tabular}{|c|c|c|c|c|c|c|c|c|c|c|}
\hline \multirow[t]{3}{*}{ Characteristic } & \multicolumn{10}{|c|}{ Models } \\
\hline & \multicolumn{2}{|c|}{ Poisson } & \multicolumn{2}{|r|}{ Cox } & \multicolumn{2}{|c|}{ AG } & \multicolumn{2}{|c|}{ PWP } & \multicolumn{2}{|c|}{ Frailty } \\
\hline & PR & $95 \% \mathrm{Cl}$ & HR & $95 \% \mathrm{Cl}$ & HR & $95 \% \mathrm{Cl}$ & HR & $95 \% \mathrm{Cl}$ & $\mathrm{HR}$ & $95 \% \mathrm{Cl}$ \\
\hline \multicolumn{11}{|l|}{ Sex } \\
\hline Male & 1.000 & & 1.000 & & 1.000 & & 1.000 & & 1.000 & \\
\hline Female & 1.000 & $0.980-1.030$ & 1.040 & $0.970-1.120$ & 1.030 & $0.940-1.130$ & 1.010 & $0.930-1.090$ & 1.050 & $0.960-1.140$ \\
\hline Age (years) & 1.001 & $1.000-1.001$ & 1.004 & $1.002-1.010$ & 1.003 & $1.001-1.010$ & 1.004 & $1.002-1.010$ & 1.050 & $1.003-1.010$ \\
\hline $\begin{array}{l}\text { Length of stay } \\
\text { (days) }\end{array}$ & 1.003 & $1.002-1.005$ & 1.010 & $1.009-1.010$ & 1.010 & $1.007-1.010$ & 1.010 & $1.007-1.010$ & 1.015 & $1.011-1.020$ \\
\hline \multicolumn{11}{|l|}{$\begin{array}{l}\text { Death (during next } \\
\text { admission) }\end{array}$} \\
\hline No & 1.000 & & 1.000 & & 1.000 & & 1.000 & & 1.000 & \\
\hline Yes & 1.430 & $1.310-1.560$ & 13.940 & $12.330-15.760$ & 12.240 & $10.390-14.410$ & 11.200 & $9.440-13.280$ & 12.040 & $10.280-14.090$ \\
\hline \multicolumn{11}{|l|}{ Specialty } \\
\hline Surgery & 1.000 & & 1.000 & & 1.000 & & 1.000 & & 1.000 & \\
\hline Obstetrics & 1.700 & $1.530-1.900$ & 1.970 & $1.630-2.390$ & 1.800 & $1.440-2.270$ & 1.470 & $1.170-1.870$ & 0.920 & $0.730-1.170$ \\
\hline Internal medicine & 1.100 & $1.060-1.150$ & 1.460 & $1.310-1.610$ & 1.490 & $1.330-1.670$ & 1.460 & $1.310-1.620$ & 1.710 & $1.530-1.920$ \\
\hline Pediatrics & 1.130 & $0.950-1.340$ & 1.620 & $1.110-2.380$ & 1.660 & $1.070-2.570$ & 1.680 & $1.100-2.570$ & 1.900 & $1.230-2.940$ \\
\hline \multicolumn{11}{|l|}{ ICD Group } \\
\hline Appendix (REF) & 1.000 & & 1.000 & & 1.000 & & 1.000 & & 1.000 & \\
\hline $\begin{array}{l}\text { Infectious } \\
\text { and parasitic }\end{array}$ & 1.020 & $0.900-1.150$ & 1.280 & $0.920-1.780$ & 1.480 & $1.050-2.090$ & 1.360 & $0.970-1.900$ & 1.160 & $0.810-1.680$ \\
\hline Neoplams & 1.040 & $0.930-1.180$ & 1.620 & $1.160-2.270$ & 1.710 & $1.220-2.410$ & 1.570 & $1.120-2.210$ & 1.390 & $0.950-2.020$ \\
\hline $\begin{array}{l}\text { Endocrine, } \\
\text { nutritional, } \\
\text { and metabolic }\end{array}$ & 1.170 & $1.050-1.310$ & 1.550 & $1.140-2.100$ & 1.800 & $1.290-2.510$ & 1.620 & $1.170-2.240$ & 1.520 & $1.080-2.140$ \\
\hline $\begin{array}{l}\text { Blood, blood- } \\
\text { forming organs, } \\
\text { and immunity }\end{array}$ & 1.100 & $0.940-1.280$ & 1.440 & $0.980-2.110$ & 1.610 & $1.080-2.400$ & 1.520 & $1.020-2.270$ & 1.490 & $0.950-2.320$ \\
\hline $\begin{array}{l}\text { Esophagus, } \\
\text { stomach, and } \\
\text { duodenum }\end{array}$ & 1.050 & $0.920-1.200$ & 1.430 & $0.990-2.060$ & 1.440 & $1.000-2.090$ & 1.390 & $0.960-2.000$ & 1.260 & $0.830-1.930$ \\
\hline Hernias & 1.010 & $0.920-1.120$ & 1.350 & $0.970-1.860$ & 1.410 & $1.020-1.950$ & 1.330 & $0.970-1.840$ & 1.290 & $0.910-1.830$ \\
\hline $\begin{array}{l}\text { Intestines and } \\
\text { peritoneum }\end{array}$ & 1.080 & $0.940-1.230$ & 1.800 & $1.260-2.560$ & 2.000 & $1.390-2.880$ & 1.800 & $1.260-2.570$ & 1.710 & $1.160-2.540$ \\
\hline $\begin{array}{l}\text { Other digestive } \\
\text { diseases }\end{array}$ & 1.070 & $0.950-1.210$ & 1.920 & $1.400-2.640$ & 2.160 & $1.560-2.990$ & 1.950 & $1.420-2.690$ & 1.820 & $1.270-2.600$ \\
\hline Liver & 1.350 & $1.150-1.580$ & 2.350 & $1.650-3.340$ & 2.880 & $1.920-4.330$ & 2.440 & $1.650-3.610$ & 2.660 & $1.760-4.030$ \\
\hline $\begin{array}{l}\text { Gallbladder, } \\
\text { bile ducts, } \\
\text { and pancreas }\end{array}$ & 1.080 & $0.980-1.190$ & 2.070 & $1.560-2.760$ & 2.190 & $1.630-2.940$ & 2.020 & $1.510-2.690$ & 1.990 & $1.440-2.740$ \\
\hline Nervous system & 1.020 & $0.920-1.130$ & 1.560 & $1.170-2.090$ & 1.750 & $1.270-2.370$ & 1.610 & $1.200-2.150$ & 1.340 & $0.980-1.850$ \\
\hline $\begin{array}{l}\text { Cardiovascular, } \\
\text { exc. vein and } \\
\text { lymphatic diseases }\end{array}$ & 1.100 & $1.010-1.210$ & 1.660 & $1.260-2.170$ & 1.970 & $1.480-2.620$ & 1.700 & $1.290-2.240$ & 1.610 & $1.200-2.180$ \\
\hline $\begin{array}{l}\text { Vein and } \\
\text { lymphatic } \\
\text { diseases }\end{array}$ & 1.070 & $0.960-1.200$ & 1.710 & $1.250-2.340$ & 1.790 & $1.290-2.490$ & 1.650 & $1.190-2.280$ & 1.510 & $1.060-2.140$ \\
\hline $\begin{array}{l}\text { Acute respiratory } \\
\text { infections }\end{array}$ & 1.020 & $0.910-1.140$ & 1.160 & $0.850-1.580$ & 1.320 & $0.960-1.820$ & 1.250 & $0.910-1.720$ & 1.100 & $0.780-1.550$ \\
\hline $\begin{array}{l}\text { Other respiratory } \\
\text { diseases }\end{array}$ & 0.990 & $0.860-1.130$ & 1.840 & $1.260-2.700$ & 2.050 & $1.400-3.020$ & 1.750 & $1.180-2.590$ & 1.570 & $1.040-2.380$ \\
\hline
\end{tabular}

(continues) 


\begin{tabular}{|c|c|c|c|c|c|c|c|c|c|c|}
\hline \multirow[t]{3}{*}{ Characteristic } & \multicolumn{10}{|c|}{ Models } \\
\hline & \multicolumn{2}{|c|}{ Poisson } & \multicolumn{2}{|c|}{ Cox } & \multicolumn{2}{|c|}{$A G$} & \multicolumn{2}{|c|}{ PWP } & \multicolumn{2}{|c|}{ Frailty } \\
\hline & PR & $95 \% \mathrm{Cl}$ & $\mathrm{HR}$ & $95 \% \mathrm{Cl}$ & $\mathrm{HR}$ & $95 \% \mathrm{Cl}$ & $\mathrm{HR}$ & $95 \% \mathrm{Cl}$ & $\mathrm{HR}$ & $95 \% \mathrm{Cl}$ \\
\hline $\begin{array}{l}\text { Chronic lower } \\
\text { respiratory } \\
\text { diseases }\end{array}$ & 1.200 & $1.080-1.350$ & 1.780 & $1.330-2.400$ & 1.950 & $1.420-2.690$ & 1.680 & $1.240-2.290$ & 1.590 & $1.130-2.230$ \\
\hline Urinary diseases & 1.090 & $0.980-1.210$ & 1.400 & $1.040-1.900$ & 1.460 & $1.060-2.010$ & 1.380 & $1.010-1.900$ & 1.380 & $0.980-1.950$ \\
\hline $\begin{array}{l}\text { Male genital } \\
\text { diseases }\end{array}$ & 0.990 & $0.840-1.170$ & 1.130 & $0.630-2.010$ & 1.200 & $0.670-2.160$ & 1.150 & $0.640-2.050$ & 1.090 & $0.590-2.030$ \\
\hline $\begin{array}{l}\text { Female genital } \\
\text { diseases }\end{array}$ & 1.050 & $0.950-1.160$ & 1.350 & $0.980-1.840$ & 1.400 & $1.010-1.920$ & 1.350 & $0.980-1.850$ & 1.300 & $0.920-1.840$ \\
\hline Renal failure & 1.950 & $1.720-2.230$ & 4.640 & $3.400-6.340$ & 6.260 & $4.310-9.080$ & 4.060 & $2.870-5.740$ & 5.270 & $3.720-7.470$ \\
\hline $\begin{array}{l}\text { Pregnancy, } \\
\text { childbirth, and } \\
\text { puerperium }\end{array}$ & 1.240 & $1.110-1.390$ & 3.790 & $2.840-5.070$ & 3.930 & $2.880-5.370$ & 3.530 & $2.590-4.810$ & 5.390 & $3.840-7.560$ \\
\hline $\begin{array}{l}\text { Skin and } \\
\text { subcutaneous } \\
\text { tissue }\end{array}$ & 1.130 & $1.000-1.270$ & 2.250 & $1.650-3.090$ & 2.590 & $1.860-3.600$ & 2.200 & $1.590-3.040$ & 2.060 & $1.450-2.910$ \\
\hline $\begin{array}{l}\text { Musculoskeletal } \\
\text { and connective } \\
\text { tissue }\end{array}$ & 1.020 & $0.910-1.150$ & 1.530 & $1.090-2.150$ & 1.730 & $1.220-2.450$ & 1.550 & $1.100-2.180$ & 1.360 & $0.940-1.960$ \\
\hline $\begin{array}{l}\text { Injuries and } \\
\text { poisoning }\end{array}$ & 0.990 & $0.920-1.070$ & 1.110 & $0.860-1.430$ & 1.150 & $0.890-1.490$ & 1.130 & $0.880-1.470$ & 1.050 & $0.800-1.390$ \\
\hline Other diseases & 1.030 & $0.930-1.130$ & 1.200 & $0.890-1.600$ & 1.310 & $0.970-1.770$ & 1.230 & $0.910-1.650$ & 1.050 & $0.770-1.450$ \\
\hline \multicolumn{11}{|l|}{ Frailty } \\
\hline Variance & & & & & & & & & 1.510 & \\
\hline
\end{tabular}

$A G=$ Andersen-Gill; PWP = Prentice, Williams, and Person; PR = prevalence ratio; $H R=$ hazard ratio.

control for co-morbidities, as in Martins et al. 23, because secondary diagnosis was not filled out in $80.0 \%$ of the records. The inclusion of socioeconomic variables would also help understand other determinants of readmission. As there is no such information in the data set, place of residence could be a proxy for individual socioeconomic level 24,25 . In addition, geographic access and distance from home to hospital could be analyzed as well, although geocoding of addresses can be a problem in deprived areas of Brazil. Besides, the addition of spatial effects in survival models is still not a standard technique.

Analysis of the cause of hospital admission posed another challenge. An initial attempt to work with ICD chapters was abandoned because this classification added no meaningful information to the analysis of readmissions. The ICD groups created on the basis of clinical experience, peculiarities of the data set, and exploratory survival modeling were adequate for our purposes.

The selection bias originated by the exclusion of patients with admissions exclusively to obstetrics wards favored the more severely ill obstetric patients who were also admitted to other wards. The results reflected this choice, as expected, but the alternative of excluding all obstetrics admissions was not considered appropriate, since part of the admissions history of many patients would be incomplete. On the other hand, to include patients with admissions only related to obstetrics would not help understand the readmissions problem, since it would be related to normal pregnancy and childbirth.

Except for obstetrics admissions, more than half $(53.0 \%)$ of the publicly funded admissions of Betim inhabitants in 1998 and $66.0 \%$ of all hospital deaths occurred in the Betim Regional Public Hospital 26, emphasizing not only this public hospital's fundamental role in the city, but also the fact that its patients presented more severe diseases. Therefore, they could be more prone to readmissions than patients admitted to other hospitals.

The Hospital Information System is not prepared either to link registries of different admissions of the same patient or to link them with the Mortality Information System. It was only possible to follow each patient along all admissions in the Betim Regional Public Hospital using local identifiers.

Therefore, our working hypothesis was that the patients were not admitted to other hospi- 
Table 4

Model comparison, admissions to Betim Regional Public Hospital, individuals over 14 years of age. Minas Gerais State, Brazil, $1996 / 2000$.

\begin{tabular}{|c|c|c|c|c|c|c|c|c|c|c|}
\hline \multirow[t]{3}{*}{ Characteristic } & \multicolumn{10}{|c|}{ Models } \\
\hline & \multicolumn{2}{|c|}{ Poisson } & \multicolumn{2}{|c|}{ Cox } & \multicolumn{2}{|c|}{ AG } & \multicolumn{2}{|c|}{ PWP } & \multicolumn{2}{|c|}{ Frailty } \\
\hline & PR & $95 \% \mathrm{Cl}$ & HR & $95 \% \mathrm{Cl}$ & $\mathrm{HR}$ & $95 \% \mathrm{Cl}$ & HR & $95 \% \mathrm{Cl}$ & $\mathrm{HR}$ & $95 \% \mathrm{Cl}$ \\
\hline \multicolumn{11}{|l|}{ Sex } \\
\hline Male & 1.000 & & 1.000 & & 1.000 & & 1.000 & & 1.000 & \\
\hline Female & 0.990 & $1.030-0.960$ & 0.910 & $0.800-1.360$ & 0.940 & $0.780-1.130$ & 0.970 & $0.850-1.110$ & 0.870 & $0.730-1.040$ \\
\hline Age (years) & 0.993 & 0.987-0.999 & 0.934 & $0.913-0.956$ & 0.935 & $0.902-0.970$ & 0.966 & $0.939-0.994$ & 0.963 & $0.937-0.989$ \\
\hline $\begin{array}{l}\text { Length of stay } \\
\text { (days) }\end{array}$ & 1.004 & $1.003-1.006$ & 1.014 & $1.010-1.017$ & 1.014 & $1.011-1.018$ & 1.015 & $1.011-1.019$ & 1.015 & $1.008-1.021$ \\
\hline \multicolumn{11}{|l|}{ Specialty } \\
\hline Surgery & 1.000 & & 1.000 & & 1.000 & & 1.000 & & 1.000 & \\
\hline $\begin{array}{l}\text { Obstetrics and } \\
\text { internal medicine }\end{array}$ & 1.003 & $0.090-1.180$ & 1.110 & $0.750-1.640$ & 1.100 & $0.680-1.770$ & 1.060 & $0.700-1.610$ & 1.210 & $0.790-1.870$ \\
\hline Pediatrics & 0.960 & $0.870-1.050$ & 0.630 & $0.460-0.860$ & 0.620 & $0.440-0.900$ & 0.840 & $0.610-1.150$ & 1.080 & $0.770-1.550$ \\
\hline \multicolumn{11}{|l|}{ ICD Group } \\
\hline Hernias (REF) & 1.000 & & 1.000 & & 1.000 & & 1.000 & & 1.000 & \\
\hline $\begin{array}{l}\text { Infectious } \\
\text { and parasitic }\end{array}$ & 1.040 & $0.890-1.210$ & 2.130 & $1.240-3.660$ & 2.220 & $1.250-3.960$ & 1.740 & $1.000-3.000$ & 1.860 & $0.980-3.530$ \\
\hline $\begin{array}{l}\text { Blood, blood- } \\
\text { forming organs, } \\
\text { and immunity }\end{array}$ & 1.500 & $1.210-1.860$ & 6.690 & $3.570-12.530$ & 9.050 & $4.250-19.290$ & 5.130 & $2.710-9.970$ & 5.060 & $2.340-10.960$ \\
\hline Appendix & 1.080 & $0.910-1.280$ & 2.280 & $1.220-4.270$ & 2.210 & $1.150-4.250$ & 2.230 & $1.170-4.240$ & 4.250 & $1.850-9.810$ \\
\hline $\begin{array}{l}\text { Intestines and } \\
\text { peritoneum }\end{array}$ & 1.120 & $0.930-1.360$ & 2.580 & $1.390-4.790$ & 3.330 & $1.750-6.340$ & 2.120 & $1.170-3.860$ & 2.640 & $1.280-5.410$ \\
\hline Nervous system & 1.260 & $1.050-1.520$ & 6.040 & $3.340-10.920$ & 9.170 & $4.610-18.240$ & 4.730 & $2.610-8.570$ & 3.900 & $1.960-7.740$ \\
\hline $\begin{array}{l}\text { Eye, ear, and } \\
\text { mastoid process }\end{array}$ & 1.050 & $0.820-1.330$ & 4.170 & $1.920-9.020$ & 5.150 & $2.320-11.430$ & 4.170 & $2.010-8.640$ & 5.530 & $2.190-13.990$ \\
\hline Circulatory & 1.270 & $0.990-1.620$ & 4.770 & $2.410-9.430$ & 5.080 & $2.420-10.630$ & 2.610 & $1.400-4.890$ & 2.710 & $1.810-6.250$ \\
\hline $\begin{array}{l}\text { Acute respiratory } \\
\text { infections }\end{array}$ & 1.090 & $0.940-1.260$ & 2.410 & $1.420-4.090$ & 2.880 & $1.630-5.090$ & 2.080 & $1.230-3.490$ & 2.250 & $1.210-4.170$ \\
\hline $\begin{array}{l}\text { Other respiratory } \\
\text { diseases }\end{array}$ & 0.970 & $0.830-1.130$ & 1.360 & $0.700-2.620$ & 1.750 & $0.930-3.270$ & 1.580 & $0.880-2.870$ & 2.000 & $0.960-4.150$ \\
\hline $\begin{array}{l}\text { Chronic lower } \\
\text { respiratory } \\
\text { diseases }\end{array}$ & 1.110 & $0.950-1.310$ & 3.320 & $1.910-5.770$ & 4.250 & $2.360-7.650$ & 2.670 & $1.550-4.600$ & 2.950 & $1.550-5.630$ \\
\hline Urinary diseases & 1.070 & $0.890-1.290$ & 2.170 & $1.120-4.210$ & 2.660 & $1.160-6.120$ & 1.930 & $0.960-3.880$ & 1.690 & $0.780-3.630$ \\
\hline $\begin{array}{l}\text { Male genital } \\
\text { diseases }\end{array}$ & 1.050 & $0.850-1.300$ & 2.220 & $1.140-4.320$ & 2.170 & $1.110-4.240$ & 2.090 & $1.100-3.960$ & 2.490 & $1.060-5.850$ \\
\hline $\begin{array}{l}\text { Skin and } \\
\text { subcutaneous } \\
\text { tissue }\end{array}$ & 1.010 & $0.850-1.200$ & 1.240 & $0.640-2.400$ & 1.270 & $0.640-2.530$ & 1.000 & $0.520-1.910$ & 0.850 & $0.400-1.840$ \\
\hline $\begin{array}{l}\text { Musculoskeletal } \\
\text { and connective } \\
\text { tissue }\end{array}$ & 1.020 & $0.840-1.250$ & 2.150 & $1.070-4.310$ & 2.080 & $0.950-4.510$ & 1.810 & $0.880-3.760$ & 1.910 & $0.810-4.540$ \\
\hline $\begin{array}{l}\text { Congenital } \\
\text { anomalies }\end{array}$ & 1.180 & $1.000-1.400$ & 5.030 & $3.020-8.390$ & 5.510 & $3.160-9.610$ & 4.340 & $2.580-7.320$ & 6.990 & $3.680-13.270$ \\
\hline $\begin{array}{l}\text { Certain conditions } \\
\text { originating in the } \\
\text { perinatal period }\end{array}$ & 0.990 & $0.860-1.140$ & 1.250 & $0.730-2.130$ & 1.260 & $0.720-2.210$ & 1.240 & $0.730-2100$ & 1.430 & $0.760-2.690$ \\
\hline $\begin{array}{l}\text { Injuries and } \\
\text { poisoning }\end{array}$ & 1.000 & $0.860-1.150$ & 1.310 & $0.810-2.120$ & 1.310 & $0.790-2.180$ & 1.340 & $0.820-2.180$ & 1.550 & $0.880-2.760$ \\
\hline Other diseases & 1.080 & $0.920-1.270$ & 2.300 & $1.310-4.020$ & 2.840 & $1.580-5.090$ & 2.060 & $1.200-3.530$ & 2.100 & $1.100-4.020$ \\
\hline \multicolumn{11}{|l|}{ Frailty } \\
\hline Variance & & & & & & & & & 6.070 & \\
\hline
\end{tabular}

$\mathrm{AG}=$ Andersen-Gill; PWP $=$ Prentice, Williams, and Person; PR = prevalence ratio; HR = hazard ratio. 
tals until the end of the observation period This approach was considered adequate, since the hospital studied is the only public general hospital in Betim. The city has only three other hospitals: a public maternity hospital, a lowcomplexity hospital which serves a specific and closed community, and a small private hospital which is used by a small fraction of the population. In addition, the Municipal Public Health System was very well organized at the time, and patients tended to remain with the same hospital, particularly those that needed multiple admissions. Besides, as the data set was large, with 38 thousand patients and 47 thousand admissions, the results proved very robust and the inclusion of more admissions would not in fact have significantly influenced results. The same approach was used with other censoring situations, particularly deaths that occurred outside the Betim Regional Public Hospital.

The linkage of different databases is a complex operation 27. The implementation of a sys- tem that supplies information on all individual admissions, regardless of the health event, is under evaluation in Brazil. This system will spare several complex phases of database preparation, thereby facilitating the use of this kind of analysis by health services managers and policymakers. It will also allow taking the effect of different hospitals into account, through the introduction of a random effect related to the hospital, in addition to individual effects.

The methodologies presented in this paper are remarkably useful in health services research, helping to identify problems related to quality of information or services, and to establish priorities among diagnostic groups that are heavily associated with readmission, for purposes of more in-depth investigation. It is important to remember that any program designed to prevent readmission must distinguish between avoidable and necessary readmissions, identifying situations in which impeding re-hospitalization would be harmful to the patient.
Resumo

O objetivo foi comparar diferentes métodos de análise de sobrevivência para identificação de características associadas a uma maior chance de reinternação em um grande hospital geral. Foram analisadas as internações do Hospital Público Regional de Betim, Minas Gerais, Brasil, de julho de 1996 a junho de 2000, excluindo internações apenas em obstetrícia e os óbitos na primeira internação. Foram utilizados os modelos de Cox; Andersen-Gill (AG); Prentice, Williams e Peterson (PWP) e de efeitos aleatórios, tendo o tempo entre as internações ou até o óbito ou até o final do periodo de observação como variável resposta. Um modelo de Poisson para o número de internações foi ajustado para efeitos comparativos. Considerando os resultados bastante próximos dos modelos PWP e de fragilidade, recomenda-se o ajuste dos dois e que, caso haja discrepância importante entre eles, o modelo PWP seja preferido apenas nos casos em que seja possível a incorporação de mais variáveis clínicas. Caso contrário, sugerimos o uso do modelo de fragilidade, pois ele leva em conta características individuais não mensuradas. A aplicação da metodologia proposta pode sugerir grupos de diagnósticos prioritários para uma investigação mais aprofundada.

Hospitais Gerais; Readmissão Hospitalar; Análise de Sobrevivência

\section{Contributors}

The three authors jointly designed the study, chose the analytical methods, and reviewed the final version. M. S. M. Castro conducted the analyses and drafted the article. 
1. Evans RL, Hendricks RD, Lawrence KV, Bishop DS. Identifying factors associated with health care use: a hospital-based risk-screening index. Soc Sci Med 1988; 9:947-53.

2. Holloway JJ, Medendorp SV, Bromberg J. Risk factors for early readmission among veterans. Health Serv Res 1990; 25:215-37.

3. Zook CJ, Savickis SF, Moore FD. Repeated hospitalizations for the same disease: a multiplier of national health care costs. Milbank Mem Fund Q Health Soc 1980; 58:454-71.

4. Schroeder AS, Showstack JA, Roberts HE. Frequency and clinical description of high-cost patients in 17 acute-care hospitals. N Engl J Med 1979; 300:1306-9.

5. Zook CJ, Moore FD. High-cost users of medical care. N Engl J Med 1980; 302:996-1002.

6. Boult C, Dowd B, McCaffrey D, Boult L, Hernandez R, Krulewitch H. Screening elders for risk of hospital admission. J Am Geriatr Soc 1993; 41: 811-7.

7. Anderson GF, Steinberg EP. Predicting hospital readmissions in the Medicare population. Inquiry $1985 ; 22: 251-8$.

8. Roos NP, Shapiro E, Tate R. Does a small minority of elderly account for a majority of health care expenditures? A sixteen-year perspective. Milbank Q 1990; 67:347-69.

9. Castro MSM, Travassos C, Carvalho MS. Fatores associados às internações hospitalares no Brasil. Ciênc Saúde Coletiva 2002; 7:795-811.

10. Smith DM, Norton JA, McDonald CJ. Non-elective re-admissions of medical patients. J Chronic Dis 1985; 38:213-24.

11. Fethke CC, Smith IM, Johnson N. "Risk" factors affecting readmission of the elderly into the health care system. Med Care 1986; 24:429-37.

12. Kennedy BS, Kasl SV, Vaccarino V. Repeated hospitalizations and self-rated health among the elderly: a multivariate failure time analysis. Am J Epidemiol 2001; 153:232-41.

13. Schumann J, Ostfeld A, Willard H. Discharge planning in an acute hospital. Arch Phys Med Rehabil 1976; $57: 343$

14. Heggestad T. Do hospital length of stay and staffing ratio affect elderly patients' risk of readmission? A nationwide study of Norwegian hospitals. Health Serv Res 2002; 37:647-65.
15. Meiners M, Coffey R. Hospital DRG and the need for long-term care services: an empirical analysis. Health Serv Res 1985; 20:359-84.

16. Riley G, Lubitz J. Outcomes of surgery in the Medicare-aged population: rehospitalization after surgery. Health Care Financ Rev 1986; 8:23-34.

17. Organização Mundial da Saúde. Manual da classificação estatística internacional de doenças, lesões e causas de óbitos - nona conferência de revisão. São Paulo: Centro Brasileiro de Classificação de Doenças em Português; 1985.

18. Organização Mundial da Saúde. Classificação estatística internacional de doenças e problemas relacionados à saúde, 10a revisão. v. 1. São Paulo: Centro Colaborador da OMS para a Classificação de Doenças em Português; 1995.

19. Castro MSM, Carvalho MS. Agrupamento da Classificação Internacional de Doenças para análise de reinternações hospitalares. Cad Saúde Pública 2005; 21:317-23.

20. Cox DR. Regression models and life-tables. J Royal Statistical Soc B 1972; 34:187-201.

21. Therneau TM, Grambsch PM. Modeling survival data: extending the Cox model. New York: Springer; 2000.

22. Ihaka R, Gentleman R. R: a language for data analysis and graphics. Journal of Computational and Graphical Statistics 1996; 5:299-314.

23. Martins M, Travassos C, Noronha JC. Sistema de Informações Hospitalares como ajuste de risco em índices de desempenho. Rev Saúde Pública 2001; 35:185-92.

24. Krieger N. Overcoming the absence of socioeconomic data in medical records: validation and application of a census-based methodology. Am J Public Health 1992; 82:703-10.

25. Hofer T, Wolfe RA, Tedeschi PJ, McMahon LF, Griffith JR. Use of community versus individual socioeconomic data in predicting variation in hospital use. Health Serv Res 1998; 33:243-59.

26. Castro MSM. Comparação entre as internações de moradores de Betim no Hospital Público Regional de Betim e em outros hospitais do Sistema Único de Saúde no Estado de Minas Gerais. Cad Saúde Coletiva 2001; 9:53-98.

27. Bell RM, Keesey J, Richards T. The urge to merge: linking vital statistics records and Medicaid claims. Med Care 1994; 32:1004-18.

Submitted on $10 /$ Oct $/ 2004$

Final version resubmitted on 14/Jun/2004 Approved on 09/Aug/2004 